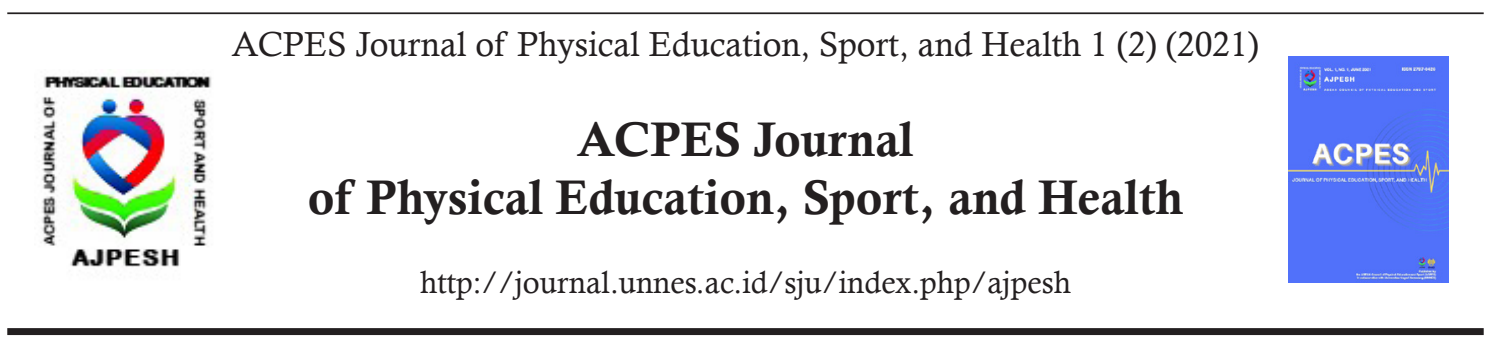

\title{
Motion Analysis of Long-Distance Drive in Woodball Athletes
}

\author{
Fajar Awang Irawan ${ }^{1 \bowtie}$, Hanif Putra Toma ${ }^{1}$, Dhias Fajar Widya Permana ${ }^{1}$, Nur Suciati $^{2}$, \\ Preeyaporn Gulsirirat ${ }^{3}$
}

${ }^{1}$ Deparment of Sports Science, Universitas Negeri Semarang, Indonesia

${ }^{2} \mathrm{SMK}$ NU Ungaran, Indonesia

${ }^{3}$ Deparment of Physical Education, Srinakharinwirot University, Thailand

DOI: https://doi.org/10.15294/ajpesh.v1i2.49972

\section{Article Info}

Article History

Submitted 2021-09-16

Revised 2021-10-29

Accepted 2021-11-17

Keywords

Motion Analysis,

Flat Serve, Tennis

\begin{abstract}
The purpose of this study was to analyze the motion of long-distance drive in woodball athletes. The method in this study using quantitative descriptive using observation by Video Recording. The total sample used in this study 8 woodball athletes Semarang State University and all of them were willing to participate in the study by signing the informed consent form. This study uses data analysis techniques using the Kinovea application software Version 0.8.15. The results found that the preparation phase obtaining appropriate criteria, with an average score of 4 . The prefix phase in this movement was of 3.8 with appropriate criteria and the implementation phase of 3.7 with appropriate criteria. The follow-through phase obtained an average score of 3.4 with almost appropriate criteria. Overall, the average in the motion analysis is 3.7 with the appropriate category. The conclusion of this study found that motion analysis of long-distance drive in woodball athletes are in the appropriate category. This study also showed quite effective and quite efficient based on the video analysis used. The limitation in this study still focuses on the kinetic data. Future research is expected to improve the quality of the drive and also minimize the occurrence of injuries.
\end{abstract}

\section{INTRODUCTION}

Sport is one of the basic necessities that need to be considered by every individual. Sport is a form of human physical activity that strives for the formation of a complete human being who is physically and has a good mentality (Yazid et al., 2016). The information that can be explained is that sports should be a priority in the pattern of everyday human life. Sport is also a positive activity for humans and good to be done routinely because it affects physical, spiritual, mental maintenance and even in character building (Chandrasegaran et al., 2020; Chang \& Lee, 2017; Iragraha et al., 2019). The purpose of exercising will be easy to achieve if the type of sport is carried out according to the procedure and understand the basic techniques of the sport itself. But lately many individuals ignore the understanding of basic techniques to start doing a type of sport, especially sports that aim for achievement. This is very unfortunate if in fact sport is only an excuse when in its development with the main reason being the difficulty of athletes in developing to support achievement because they ignore basic techniques. The motion analysis carried out basically contains elements of effectiveness and efficiency of motion. In addition, a deep understanding of basic techniques can also reduce the risk of injury. According to Simatupang (2016) sports injuries are abnormalities that occur in the body that result in pain, heat, redness, swelling, and dysfunction in muscles, tendons, ligaments, joints and

$\square$ Correspondence Author:

Sekaran, Gunungpati, Semarang, Indonesia

e-ISSN 2797-0426

E-mail: fajarawang@mail.unnes.ac.id 
bones properly due to excessive motion activities or accidents. Basic techniques can also be likened to the foundation in all types of sports, one of which is Woodball. According to Irawan \& Long-Ren (2015) If applied correctly and followed regularly, it has the potential to reduce the incidence of sports injuries by up to $50 \%$. According to Dewi \& Sukadiyanto (2015) Dewi, (2016) and Dewi \& Broto, (2019) explained that wooball is a sport that is played outdoors, can be played in teams and individually and the game system is by hitting the ball gradually until it enters the gate. Long-distance stroke is one of the types of strokes used on the fairway with a maximum of $130 \mathrm{~m}$. According to Putri (2018), it is explained that optimization in long-range shots is a very important focus of attention. The optimization in question is the right hit on the target where the ball must move as far as possible to approach the gate.

The Student Activity Unit of Universitas Negeri Semarang Semarang State University Woodball Student Activity Unit is a forum for students who have an interest in woodball sports. Not only that, this forum is also a bridge in obtaining achievements in sports. It is evident from the achievements that have been obtained by Universitas Negeri Semarang woodball athletes, including representing Indonesia in the World University Woodball Championship in Malaysia and successfully obtaining 2 gold, 2 silver and 3 bronze medals. Then at the next event, the 10th Asian Woodball University Championship in Beoun-gun, South Korea, the UNNES Woodball team got a proud achievements from the 4 categories that were contested, winning 3 gold medals and 1 silver medal.

Based on the explanation above, the author made observations at the Universitas Negeri Semarang Woodball Athlete's practice session on January 23, 2021 at the Mini Golf And Driving Range Course, Universitas Negeri Semarang. From the data in the field, it turns out that there are still discrepancies in doing long-distance shots starting from (1) the arm and shoulder coordination is not precise in doing the full back swing (2) the body is not leaning and the fulcrum is not fully on the right foot and the hip is not rotated to the right (3) the down swing movement is not aligned (4) the weight is not shifted to the left side (5) in the follow thourgh movement the hips and chest are still straight ahead and not looking at the target. Rusmania, (2015) in his research entitled Identification of Woodball Sports Hitting Skills in this study explained that the mallet movement above the head (full back swing) will increase the potential energy of the mallet. The potential energy in the mallet will be converted into kinetic energy gradually when doing the down swing movement. The higher the potential energy of the mallet, the higher its kinetic energy (Irawan, 2019). The purpose of this study was to analyze the motion of long-distance drive in woodball athletes. The results of this study are expected to improve the quality of the long-distance drive and can also minimize the occurrence of injuries.

\section{METHOD}

The method in this study using quantitative descriptive using observation by Video Recording. This study explains information in descriptive form and only describes data in descriptive form. The sampling technique used in this study was a saturated sampling technique. Saturated sampling technique itself is often used when the population is less than 30 people. The total sample used in this study amounted to 8 woodball athletes Semarang State University and all of them were willing to participate in the study by signing the informed consent form. This research has been declared to have passed the Ethical Clerance (EC) Universitas Negeri Semarang with number 051/KEPK/EC/2021.

This study uses data analysis techniques using the Kinovea application software (Muhammad et al., 2019) Version 0.8.15. In this analysis, there are video analysis series equipment facilities that make the phases and stages of the woodball long-distance drive movement can be seen in detail and the analysis process becomes easier. The results of this study analyzed the long-distance drive in woodball with indicator parameters such as distance $(\mathrm{m})$, speed $(\mathrm{m} / \mathrm{s})$, flexion angle $\left({ }^{\circ}\right)$, hip angle $\left(^{\circ}\right)$, and time (s). This study focused on the time of the drive, the speed of the drive, the trunk of the body, the distance of the mallet, and the flexion of the elbow. In addition, the researchers also calculated the kinematic data of long-distance drive through 4 phases, namely the preparation phase, the prefix phase, the implementation phase and the follow-up phase. The sampling technique in this study using purposive sampling with the criteria of athletes who are members of the UNNES Woodball team and have practiced for at least one year and have participated in at least Regional Championships. 


\section{RESULT AND DISCUSION}

The method in this study using quantitative descriptive using observation by Video Recording. This study explains information in descriptive form and only describes data in descriptive form. The sampling technique used in this study was a saturated sampling technique. Saturated sampling technique itself is often used when the population is less than 30 people. The total sample used in this study amounted to 8 woodball athletes Semarang State University and all of them were willing to participate in the study by signing the informed consent form. This research has been declared to have passed the Ethical Clerance (EC) Universitas Negeri Semarang with number 051/KEPK/EC/2021.

This study uses data analysis techniques using the Kinovea application software (Muhammad et al., 2019) Version 0.8.15. In this analysis, there are video analysis series equipment facilities that make the phases and stages of the woodball long-distance drive movement can be seen in detail and the analysis process becomes easier. The results of this study analyzed the long-distance drive in woodball with indicator parameters such as distance $(\mathrm{m})$, speed $(\mathrm{m} / \mathrm{s})$, flexion angle $\left(^{\circ}\right)$, hip angle $\left(^{\circ}\right)$, and time (s). This study focused on the time of the drive, the speed of the drive, the trunk of the body, the distance of the mallet, and the flexion of the elbow. In addition, the researchers also calculated the kinematic data of long-distance drive through 4 phases, namely the preparation phase, the prefix phase, the implementation phase and the follow-up phase. The sampling technique in this study using purposive sampling with the criteria of athletes who are members of the UNNES Woodball team and have practiced for at least one year and have participated in at least Regional Championships.

Table 1. Motion Analysis of Long-Distance Drive for Woodball Athletes

\begin{tabular}{ccccc}
\hline $\mathrm{n}=8$ & Score & Criteria & Max & Min \\
\hline Preparation Phase & 4 & Appropriate & 4 & 4 \\
Prefix Phase & 3.8 & Appropriate & 4 & 3.4 \\
Implementation Phase & 3.7 & Appropriate & 4 & 3.5 \\
Follow-through Phase & 3.4 & Almost Appropriate & 4 & 3 \\
Average & 3.7 & Appropriate & 4 & 3.5 \\
\hline
\end{tabular}

The results in table 1 explain related to the analysis of long-distance drive with a total sample 8 athletes in the preparation phase obtaining appropriate criteria, with an average score of 4 . The prefix phase in this movement obtained a score of 3.8 with appropriate criteria and the implementation phase obtained an average score of 3.7 with criteria in appropriate. The follow-through phase obtained an average score of 3.4 with almost appropriate criteria. Overall, the average in the motion analysis is 3.7 with the appropriate category.

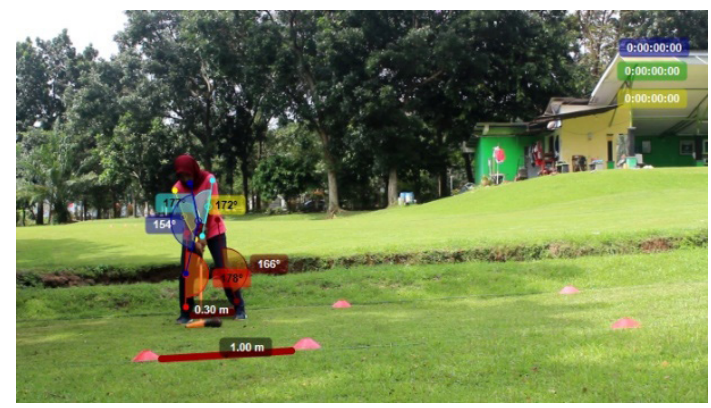

Figure 1. Preparation Phase

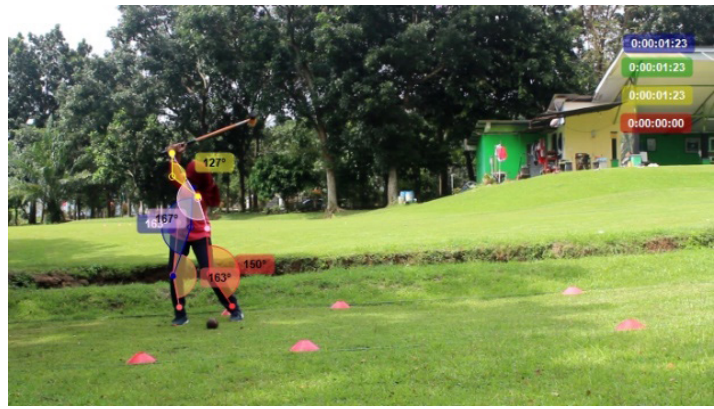

Figure 2. Prefix Phase 


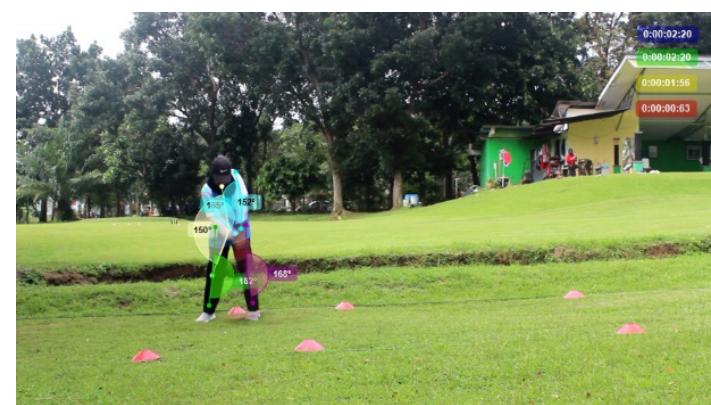

Figure 3. Implementation Phase

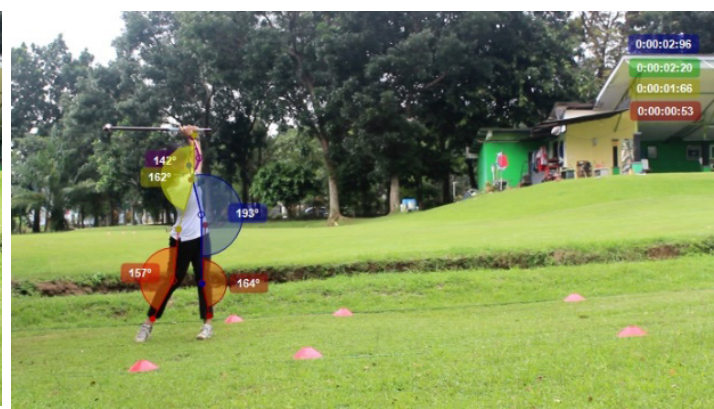

Figure 4. Follow-Through Phase

Data on the effectiveness of long-distance drive on woodball athletes of Universitas Negeri Semarang found an average active time of 2.07 second, an average mallet distance of 1.70 meters, with an average speed of 0.83 meter per second, an average trunk angle of 164.83 degrees and the mean elbow flexion angle is 164.14 degrees. The results of the long-distance drive motion analysis in this study were divided into 4 phases including the preparation phase, the prefix phase, the implementation phase, and the follow-up phase. The author also calculated the kinematic data of the woodball longdistance drive which was presented in Table 2.

Table 2. Kinematic Data Long-Distance Drive for Woodball Athletes

\begin{tabular}{|c|c|c|c|}
\hline Indicator & Mean \pm SD & Max & Min \\
\hline Drive Speed (m/s) & $3.37 \pm 0.911$ & 1.04 & 0.48 \\
\hline Drive Time (s) & $2.90 \pm 0.311$ & 3.50 & 2.54 \\
\hline \multicolumn{4}{|l|}{ Preparation Phase } \\
\hline Trunk Angle $\left(^{\circ}\right)$ & $156.57 \pm 4.429$ & 164 & 151 \\
\hline Right Elbow Flexion Angle $\left(^{\circ}\right)$ & $178.83 \pm 2.041$ & 182 & 172 \\
\hline Left Elbow Flexion Angle $\left(^{\circ}\right)$ & $170.71 \pm 8.159$ & 186 & 161 \\
\hline Right Leg Flexion Angle $\left(^{\circ}\right)$ & $174.86 \pm 5.014$ & 182 & 167 \\
\hline Left Leg Flexion Angle $\left(^{\circ}\right)$ & $165.71 \pm 4.990$ & 174 & 158 \\
\hline Foot Distance (cm) & $28.13 \pm 5,410$ & 36 & 22 \\
\hline \multicolumn{4}{|l|}{ Prefix Phase } \\
\hline Time (s) & $1.56 \pm 0.186$ & 1.90 & 1.23 \\
\hline Trunk Angle $\left(^{\circ}\right)$ & $164.83 \pm 6,24$ & 170 & 154 \\
\hline Malet Distance (m) & $1.70 \pm 0.20$ & 2.12 & 1.53 \\
\hline Left Shoulder Rotation $\left(^{\circ}\right)$ & $163.50 \pm 16.01$ & 179.00 & 138 \\
\hline Left Elbow Flexion Angle $\left(^{\circ}\right)$ & $141 \pm 21.65$ & 175 & 97 \\
\hline Right Knee Flexion Angle $\left(^{\circ}\right)$ & $169.86 \pm 6.20$ & 176 & 152 \\
\hline Left Knee Flexion Angle $\left(^{\circ}\right)$ & $151.14 \pm 3.6$ & 156 & 145 \\
\hline \multicolumn{4}{|l|}{ Implementation Phase } \\
\hline Time (s) & $0.52 \pm 0.07$ & 0.63 & 0.43 \\
\hline Trunk Angle $\left(^{\circ}\right)$ & $147.43 \pm 9.71$ & 166 & 134 \\
\hline Right Elbow Flexion Angle $\left(^{\circ}\right)$ & $164.14 \pm 7.19$ & 171 & 152 \\
\hline Left Elbow Flexion Angle $\left(^{\circ}\right)$ & $167.29 \pm 5.43$ & 177 & 161 \\
\hline Right Knee Flexion Angle $\left(^{\circ}\right)$ & $170.29 \pm 10.32$ & 182 & 158 \\
\hline Left Knee Flexion Angle $\left(^{\circ}\right)$ & $172.57 \pm 3.0$ & 177 & 168 \\
\hline \multicolumn{4}{|l|}{ Follow-through phase } \\
\hline Trunk Angle $\left(^{\circ}\right)$ & $198.86 \pm 5.52$ & 207 & 193 \\
\hline
\end{tabular}


Fajar Awang Irawan et al. / AJPESH 1 (2) (2021)

\begin{tabular}{llll} 
Right Shoulder Rotation $\left({ }^{\circ}\right)$ & $176.71 \pm 16.0$ & 196 & 151 \\
Right Elbow Flexion Angle $\left(^{\circ}\right)$ & $114.71 \pm 22.0$ & 142 & 79 \\
Right Knee Flexion Angle $\left(^{\circ}\right)$ & $149.14 \pm 7.2$ & 157 & 138 \\
Left Knee Flexion Angle $\left(^{\circ}\right)$ & $174 \pm 5.44$ & 189 & 164 \\
\hline
\end{tabular}

The kinematic data found in this study are presented in table 2 and explain the average drive speed of 3.37 meters per second. Preparation phase data with an average foot distance of $28.13 \mathrm{~cm}$ with the overall of average trunk angle, elbow flexion, and leg flexion in the appropriate category. The data prefix phase explains that the time to make a movement in this phase is an average of 1.56 seconds. In the drive implementation phase, the average mallet distance is 1.70 meters and the average trunk angle, shoulder rotation, elbow flexion, and knee flexion are in the appropriate category. So that the movement in the long-distance drive is quite effective.

Rusmania (2015) stated that paying attention to the full backswing movement correctly will increase the potential energy of the mallet. The potential energy can be converted into kinetic energy gradually when performing the down swing movement. The higher kinetic energy obtained on the mallet, the higher the power generated when the ball hits the mallet. This causes the ball to slide fast and far away after getting impact between mallet and the ball. The length of the arm also has an effect on this long-distance drive, the longer the arm, the more it will affect the distance between the mallet and the ball. The longer distance between the mallet and the ball will affect the results of the drive on the impact made (Lu \& Luo, 2014). Furthermore, the stability of the footrest in each phase also affects the results of the drive. According to Irawan et al (2020) the legs are more stable standing to be able to distribute body weight evenly over a wider area. This movement serves to increase speed and agility while walking and then provides stability and flexibility after performing core movements. According to Irawan \& Long-Ren (2015) if this movement is applied correctly and followed regularly it will potentially reduce the incidence of sports injuries by up to $50 \%$.

Overall time achievement in long-distance drive for woodball athletes at the Universitas Negeri Semarang in the Less Effective category. This is because the pause motion when hitting takes too long to move on to the next phase. According to Putri (2018) study explained that optimization in longdistance drive is a very important point of attention, the optimization in question is hitting the right target where the ball must move as far as possible closer to the gate from the starting area and not out of the fairway or trajectory, commonly called Out off Boundary. Good technique in doing this movement by always practicing swing motion either with swing aids or not using assistive devices. Improving the skill of hitting woodball by looking at it from the point of view in the biomechanics analysis with the hope that in addition to improving the quality of the drive, it can also minimize the occurrence of injuries. According to Błaszczyszyn et al (2019)motor anticipation, and extremely developed proprioception. This is especially the case in martial arts when we deal with a kick or a blow to a specific target. Methods: The main purpose of this study was to determine the kinematic differences in the tested movement pattern among athletes with different levels of advancement in the conditions of kicking: in the air, at a target (a shield Irawan et al., (2016); Irawan \& Long-ren, (2019) basic proper initial movement exercises will produce good movement and be a protection against injury.

This is in accordance with the research data on the implementation movement with an average time in its implementation of 0.52 seconds. Other kinematic data in the form of trunk angle, elbow flexion, and knee flexion according to table 3 are appropriate and can be concluded to be effective for the implementation. The last phase of the follow-through describes the average data on trunk angle, shoulder rotation, elbow flexion, and knee flexion. In his explanation, based on the kinematic data of the study, only follow-through had an almost appropriate category. The data in this field is based on video recording analysis and assessments from the expert observations who note that there are 2 athletes who are not focused after hitting the ball with a mallet. The movements made can have an impact on the results of the drive. Locomotor movements (Irawan et al., 2021) in athletes can help to facilitate movement coordination (Irawan et al., 2021) when performing long-distance drive at woodball. So that athletes can predict and evaluate the movements performed to achieve maximum performance. Study by Agustiar \& Sultoni, (2016); Yulianingsih et al., (2020) provides recommendations on performance in playing woodball in playing more stable by controlling emotions and playing more calmly to get maximum results. This encourages athletes to be more focused and concentrated while playing. 


\section{CONCLUSION}

The results of the motion analysis of long-distance drive in woodball athletes are in the appropriate category. The results of this study also showed that it is quite effective and quite efficient based on the video analysis used. The limitation in this study still focuses on the kinetic data. This woodbal long-distance drive provides recommendations to always practice swing motion either using tools or honing woodball hitting skills by looking at it from the point of view of motion analysis. Future research is expected to improving the quality of the drive and also minimize the occurrence of injuries.

\section{ACKNOWLEDGEMENT}

The author would like to thank to the Department of Sports Science, Faculty of Sports Science, Universitas Negeri Semarang for the research permission and UNNES Woodball Team for the willingness to participate in this research.

\section{REFERENCES}

Agustiar, O. \& Sultoni, K. 2016. Hubungan Tingkat Kecemasan dengan Hasil Pukulan Gate-in pada Olahraga Woodball. Jurnal Terapan Ilmu Keolahragaan, 1 (2): 64. https://doi.org/10.17509/ jtikor.v1i2.4002

B $\square$ aszczyszyn, M., Szcz $\square$ sna, A., Pawlyta, M., Marsza $\square$ ek, M. \& Karczmit, D. 2019. Kinematic Analysis of Mae-Geri Kicks in Beginner and Advanced Kyokushin Karate Athletes. International Journal of Environmental Research and Public Health, 16 (17): 1-10. https://doi.org/10.3390/ ijerph16173155

Chandrasegaran, J., Mustafa, W.A., Jamlos, M.A. \& Idrus, S.Z.S. 2020. Design Woodball Line Detection and Monitoring System: a Preliminary Study. IOP Conference Series: Materials Science and Engineering, 917 (1): 1-13. https://doi.org/10.1088/1757-899X/917/1/012069

Chang, S.H. \& Lee, J. 2017. Teaching Striking Skills in Elementary Physical Education Using Woodball. Journal of Physical Education, Recreation \& Dance, 88 (8): 21-27. https://doi.org/10.1080/0 7303084.2017.1356767

Dewi, I.S. \& Broto, D.P. 2019. Pengembangan Tes Keterampilan Pukulan Jarak Jauh Woodball Siswa Sekolah Dasar Kelas Atas. Jurnal Pendidikan Jasmani Indonesia, 15 (2): 50-61. http://dx.doi. org/10.21831/jpji.v15i2.26663

Dewi, P.C.P. 2016. Analisis Komponen Biomotorik pada Olahraga Permainan Woodball. Jurnal Pendidikan Kesehatan Rekreasi, 1 (1): 81-87. http://download.garuda.ristekdikti.go.id/article.php ? article $=994542 \& \mathrm{val}=15182 \&$ title $=$ ANALISIS $\% 20 \mathrm{KOMPONEN} \% 20 \mathrm{BIOMOTORIK} \% 20$ PADA\%20OLAHRAGA\%20PERMAINAN\%20WOODBALL

Dewi, P.C.P. \& Sukadiyanto, S. 2015. Pengembangan Tes Keterampilan Olahraga Woodball untuk Pemula. Jurnal Keolahragaan, 3 (2): 228-240. https://doi.org/10.21831/jk.v3i2.6254

Iragraha, S.M.F., Soegiyanto, Setijono, H. \& Sugiharto. 2019. The Role of Woodball Sports Organization Universitas Negeri Semarang (Unnes) in Producing Talented Athletes. International Journal of Engineering and Advanced Technology, 9 (2): 4928-4932. https://doi.org/10.35940/ ijeat.b3308.129219

Irawan, F.A., Nurrahmad, L. \& Widya, F.D.P. 2020. The Association of Arch Height Index and Arcus Pedis on Agility : an Overview of Sport Science College Students. International Journal of Innovation, Creativity and Change, 14 (11): 669-676. https://doi.org/DOI: 10.53333/IJICC2013/141108

Irawan, F.A., Chuang, L.-R., Peng, H.-T. \& Huang, S.-K. 2016. A Biomechanical Baseball Pitching: is the Curveball has More Risk than Fastball? Chinese Journal of Sport Biomechanics, 13 (2): 55-63. https://doi.org/10.3966/207332672016121302002

Irawan, F.A. \& Long-ren, C. 2019. Baseball and Biomechanics: Injury Prevention for Baseball Pitcher. Jurnal Keolahragaan, 7 (1): 57-64. https://doi.org/DOI: https://doi.org/10.21831/ jk.v7i1.24636

Irawan, F.A. \& Long-Ren, C. 2015. Comprehensive Pitching Biomechanics and Injury Prevention for Young Baseball Pitchers-a review. Journal of Physical Education and Sport Science, 21 (1): 11-21. 
http://dx.doi.org/10.6634/JPSS-CCU.201512.21.02

Irawan, F.A., Long-Ren, C. \& Peng, H. 2019. Injury Risk of Upper Extremity in Baseball Pitchers: Kinetics Perception. Malaysian Journal of Movement, Health \& Exercise, 8 (2): 123-129. https:// doi.org/10.15282/mohe.v8i2.319

Irawan, F.A., Sutaryono, Permana, D.F.W., Billah, T.R. \& Ma'dum, M.A. 2021. Hand, Eye, and Foot Coordination Test untuk Mendeteksi Kemampuan Dasar Lokomotor. Journal of Sport Education, 3 (2): 63-74. http://dx.doi.org/10.31258/jope.3.2.85-92

Irawan, F.A., Sutaryono, Permana, D.F.W., Chuang, L. \& Yuwono. 2021. Locomotor Skills : Traditional Games in the Fundamental of Physical Activities. Al Athfaal: Jurnal Ilmiah Pendidikan Anak Usia Dini, 4 (1): 1-13. https://doi.org/10.24042/ajipaud.v4i1.8215

Kriswantoro. 2015. Teknik Dasar Bermain Woodball (M. O. Sri Haryono (ed.); 1st ed.). Semarang: Fastindo.

Kriswantoro, \& Lumbanraja, E.S. 2016. Pengaruh Jenis Pegangan terhadap Hasil Akurasi Gating pada Woodball. Journal of Sport Coaching and Physical Education, 1 (1): 1-7. https://journal. unnes.ac.id/sju/index.php/jscpe/article/view/23348

Lu, Y. \& Luo, Y. 2014. Woodball Mallet Loading Analysis during Maximal Swing Stage: a Finite Element Study. Journal of Chemical and Pharmaceutical Research, 6 (6): 756-759. https://www.jocpr. $\mathrm{com} /$ articles/woodball-mallet-loading-analysis-during-maximal-swing-stage-a-finite-elementstudy.pdf

Muhammad, H.N., Al Ardha, M.A., Priambodo, A. \& Wibowo, S. 2019. Woodball Shooting Technique Analysis in Biomechanic Perspective. Advances in Social Science, Education and Humanities Research, 362: 69-72. https://doi.org/10.2991/acpes-19.2019.15

Putri, M.W. 2018. Pengembangan Olahraga Woodball di Provinsi Jawa Tengah. Journal Power of Sports, 1 (1): 40. https://doi.org/10.25273/jpos.v1i1.1869

Rusmania, N. 2015. Identifikasi Keterampilan Pukulan Olahraga Woodball. Jurnal Pendidikan Kesehatan Rekreasi, 151: 10-17. https://doi.org/10.1145/3132847.3132886

Simatupang, N. 2016. Pengetahuan Cedera Olahraga pada Mahasiswa Fakultas Ilmu Keolahrgaan UNIMED. Jurnal Pedagogik Keolahragaan, 02 (01): 31-42. https://doi.org/10.22245/jpor. v2i1.4507

Yazid, S., Kusmaedi, N. \& Paramitha, S.T. 2016. Hubungan Konsentrasi dengan Hasil Pukulan Jarak Jauh (Long Sroke) pada Cabang Olahraga Woodball. Jurnal Terapan Ilmu Keolahragaan, 1 (1): 50. https://doi.org/10.17509/jtikor.v1i1.3903

Yulianingsih, I., Parlindungan, D. \& Ghani, M.A. 2020. Korelasi Kecerdasan Emosi dengan Hasil Pukulan Gating dalam Permainan Woodball pada Atlet Junior Pamulang Woodball Club (PWBC). Smart Sport Jurnal Olahraga dan Prestasi, 17 (1): 18-22. https://jurnal.uns.ac.id/smartsport/article/view/45340 